The timing of fjord formation and early glaciations in North and Northeast Greenland

Pedersen, Vivi K.; Larsen, Nicolaj K.; Egholm, David L.

Published in:

Geology

DOI:

$10.1130 / G 46064.1$

Publication date:

2019

Document version

Publisher's PDF, also known as Version of record

Document license:

CC BY

Citation for published version (APA):

Pedersen, V. K., Larsen, N. K., \& Egholm, D. L. (2019). The timing of fjord formation and early glaciations in North and Northeast Greenland. Geology, 47(7), 682-686. https://doi.org/10.1130/G46064.1 


\title{
The timing of fjord formation and early glaciations in North and Northeast Greenland
}

\author{
Vivi K. Pedersen ${ }^{1}$, Nicolaj K. Larsen ${ }^{1,2}$, and David L. Egholm ${ }^{1}$ \\ ${ }^{1}$ Department of Geoscience, Aarhus University, Høegh-Guldbergs Gade 2, 8000 Aarhus, Denmark \\ ${ }^{2}$ Centre for GeoGenetics, Natural History Museum of Denmark, University of Copenhagen, 1350 Copenhagen K, Denmark
}

\begin{abstract}
The timing and extent of early glaciations in Greenland and their co-evolution with the underlying landscape remain elusive. Here we use the concept of geophysical relief to estimate fjord erosion and the subsequent flexural isostatic response to erosional unloading in Northeast and North Greenland between Scoresby Sund $\left(7^{\circ} \mathrm{N}\right)$ and Independence Fjord $\left(82^{\circ} \mathrm{N}\right)$. The timing of erosion and isostatic uplift is constrained by marine sediments of late Pliocene-early Pleistocene age that are now exposed on land between $\sim 24 \mathrm{~m}$ and $230 \mathrm{~m}$ above sea level. By determining the timing of fjord formation, we can establish the early history of the Greenland Ice Sheet. We find that the Independence Fjord system must have formed by glacial erosion at average rates of $\sim 0.5-1 \mathrm{~mm} / \mathrm{yr}$ since ca. $2.5 \mathrm{Ma}$ in order to explain the current elevation of the marine Kap København Formation by erosion-induced isostatic uplift. In contrast, fjord formation in the outer parts of Scoresby Sund commenced before the Pleistocene, most likely in late Miocene, and continued throughout the Pleistocene by progressive inland fjord formation. Our results demonstrate that the inception of the Greenland Ice Sheet began in the central parts of Northeast Greenland before the Pleistocene and spread to North Greenland only at the onset of the Pleistocene.
\end{abstract}

\section{INTRODUCTION}

Understanding the behavior and long-term stability of the Greenland Ice Sheet (GrIS) is key for predicting its future course. However, our understanding of the timing and extent of early glaciations and their influence on longterm landscape formation in Greenland remains fragmented. Provisional signs of glaciation in Northeast Greenland date back to the EoceneOligocene transition (Eldrett et al., 2007; Tripati et al., 2008; Bernard et al., 2016). Glaciation resumed from the mid-Miocene (14-11 Ma; Helland and Holmes, 1997; Thiede et al., 1998; Winkler et al., 2002; Berger and Jokat, 2008) and intensified markedly from the late Miocene (Larsen et al., 1994; Butt et al., 2001; St. John and Krissek, 2002; Pérez et al., 2018). For the Pleistocene, some studies suggest a persistent GrIS for the past several million years (Bierman et al., 2014, 2016), whereas others suggest that Greenland was deglaciated almost completely for extended periods during the second half of the Pleistocene (Schaefer et al., 2016).
Largely ice-free conditions in Greenland have also been suggested for the late Plioceneearly Pleistocene, based on the marine Kap København Formation (KKF; Funder et al., 1984, 1985, 2001; Fig. 1B) with fossils that point to the presence of boreal forest-tundra and summer temperatures as much as $6-8{ }^{\circ} \mathrm{C}$ higher than at present (Bennike and Böcher, 1990; Penney, 1993; Bennike et al., 2010). The KKF sediments were deposited in a shallow marine setting (water depth $\sim 50 \mathrm{~m}$ ), but are now found $\sim 40-230 \mathrm{~m}$ above sea level (a.s.l.) (Funder et al., 1984), suggesting that they have been uplifted since deposition at ca. 2.5 Ma. Above $165 \mathrm{~m}$ a.s.1., the KKF may have experienced post-depositional glaciotectonic dislocation (Funder et al., 1984), although most sediment successions are undisturbed (Bennike, 1990). Farther south at Scoresby Sund, the similar Lodin Elv Formation (LEF) extends from 24 to $62 \mathrm{~m}$ a.s.l. (Feyling-Hanssen et al., 1983), whereas three additional occurrences on Kap Rigsdagen (Funder and Hjort, 1980), Île de France (Landvik, 1994; Bennike et al., 2002), and Store Koldewey (Bennike et al., 2010) show intermediate elevations of $100 \mathrm{~m}, 35-80 \mathrm{~m}$, and 110-130 m a.s.l., respectively (Fig. 1B).

In this study, we use the present elevations of the late Pliocene-early Pleistocene marine deposits to constrain the timing of isostatic uplift in response to fjord formation in North and Northeast Greenland. Previous efforts to estimate erosion-induced uplift in Greenland (Medvedev et al., 2008, 2013, 2018) have not constrained the timing of erosion or the inception and spatial evolution of the GrIS.

\section{METHODS}

We use the concept of geophysical relief (Small and Anderson, 1998; Champagnac et al., 2007) as a proxy for erosion. This metric defines erosion from elevation differences between present topography and a smooth surface connecting high points in the landscape within a given radius. Previous applications of geophysical relief have estimated fjord erosion in Scandinavia using a radius of $\sim 2 \mathrm{~km}$ (Steer et al., 2012). However, because the largest fjords in North and Northeast Greenland are much wider (as wide as $50 \mathrm{~km}$ ) than those in Scandinavia (up to $10 \mathrm{~km}$ wide), we use a radius of $10 \mathrm{~km}$ for fjords and a radius of $5 \mathrm{~km}$ for onshore regions, reflecting the smaller wavelength of onshore valleys compared to the much wider fjords. We note that wide bay-like regions such as the outer parts of Scoresby Sund would only be filled to sea level in their central parts, and can be regarded as intermediate regions between fjord and shelf. We have tested our approach on a synthetic landscape from a glacial landscape evolution model (Egholm et al., 2017), and were able to match the known total erosion within $\sim 6 \%$ (Fig. DR1 in the GSA Data Repository ${ }^{1}$ ). Unlike previous studies exploring erosion-induced isostatic uplift (e.g., Medvedev et al., 2008; Steer et al., 2012),

${ }^{1}$ GSA Data Repository item 2019250, Figures DR1-DR3, is available online at http://www.geosociety.org/datarepository/2019/, or on request from editing@ geosociety.org.

CITATION: Pedersen, V.K., Larsen, N.K., and Egholm, D.L., 2019, The timing of fjord formation and early glaciations in North and Northeast Greenland: Geology, v. 47, p. 682-686, https://doi.org/10.1130/G46064.1 

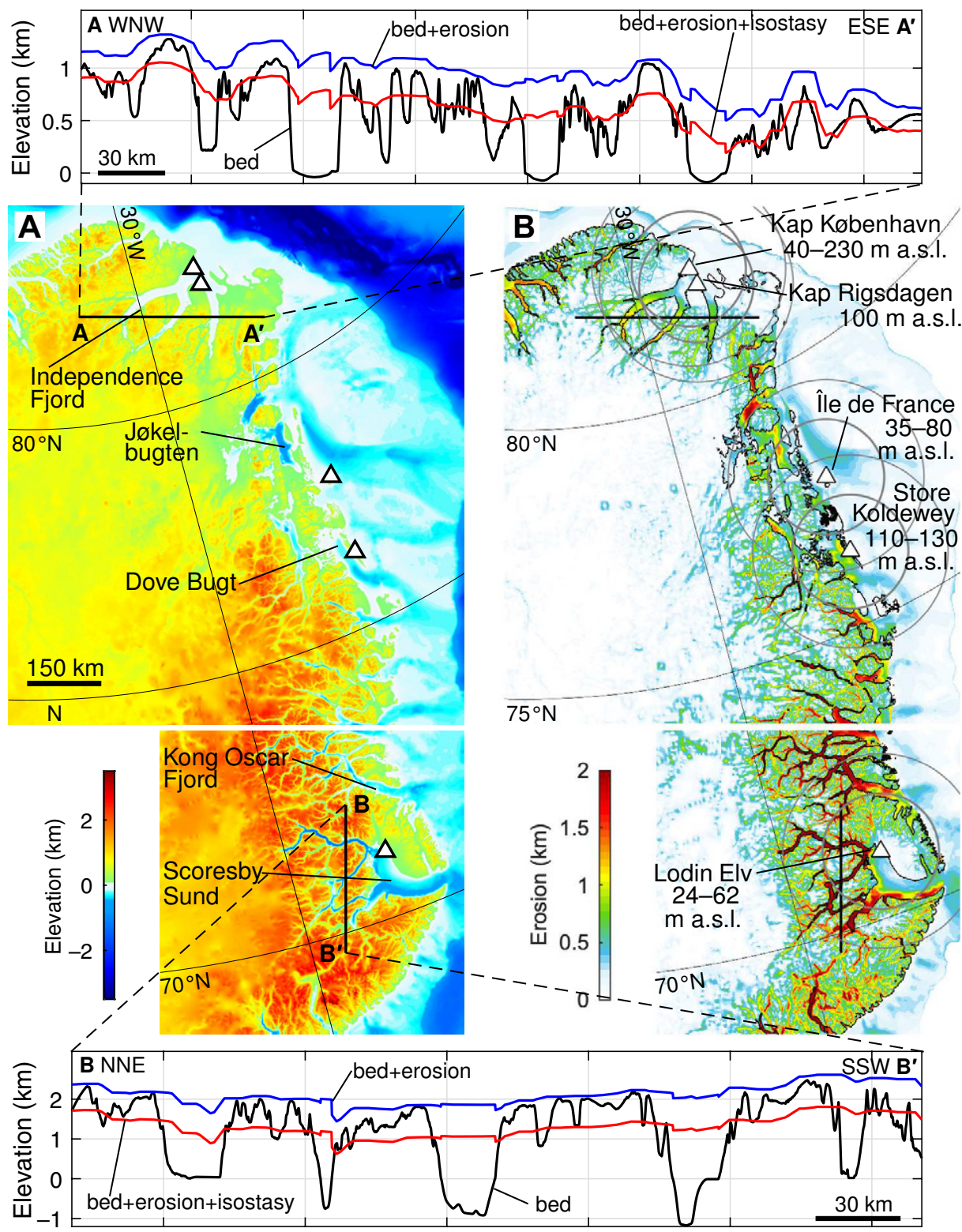

Figure 1. Rebounded subglacial topography and glacial erosion in North and Northeast Greenland. A: Subglacial topography from BedMachine v3 digital elevation model (Morlighem et al., 2017), isostatically corrected for loading of the present ice sheet. B: Estimated erosion using the geophysical relief method (see text). Also shown are localities and present elevations for the Kap København Formation and similar successions (a.s.I.-above sea level). Gray circles illustrate the contributing area for erosion-induced isostatic uplift for each locality, with the radius defined as the half-width of the analytical line-load depression (Turcotte and Schubert, 2002) for an effective elastic thickness of $20 \mathrm{~km}$ (inner circle) and $40 \mathrm{~km}$ (outer circle), respectively. Two profiles (A-A' and B-B') show rebounded subglacial topography (black), rebounded subglacial topography with added erosion (blue), and rebounded subglacial topography with added erosion and flexural isostatic response to erosion (red) for Independence Fjord system and Scoresby Sund, respectively.

we also estimate shelf erosion. Here, we use a radius of $40 \mathrm{~km}$, reflecting the large-scale troughs carved by ice streams into older sediments.

We calculate geophysical relief based on the digital elevation model BedMachine v3, which defines ice thickness and subglacial bed topography for Greenland, and the adjacent shelf bathymetry, with a grid spacing of $150 \mathrm{~m}$ (Morlighem et al., 2017). For a few regions (including Independence Fjord), synthetic fjord geometries de- transform (Makhoul, 1980), with zero-deflection gradients at the boundaries. Guided by studies of effective elastic thicknesses (EETs) in Scandinavia (Pérez-Gussinyé et al., 2004), we use an EET of $20 \mathrm{~km}$, but explore also $40 \mathrm{~km}$ (Figs. 1 and 2; Figs. DR2-DR3). We use a Young's modulus of $70 \mathrm{GPa}$, Poisson ratio of 0.25 , and densities of $950 \mathrm{~kg} / \mathrm{m}^{3}, 1020 \mathrm{~kg} / \mathrm{m}^{3}, 2500 \mathrm{~kg} / \mathrm{m}^{3}, 2670 \mathrm{~kg} / \mathrm{m}^{3}$, and $3300 \mathrm{~kg} / \mathrm{m}^{3}$ for ice, water, sediment, eroded material, and mantle, respectively.

The spatial uplift pattern we infer from the elevated marine deposits is opposite to the uplift expected from mantle convection and the Icelandic plume thermal anomaly (Steinberger et al., 2015). Previous work suggests that mantle dynamics has resulted in 200-800 m of uplift in easternmost Greenland since $5 \mathrm{Ma}$, with decreasing values toward the north (Steinberger et al., 2015). However, the low elevations of the LEF at Scoresby Sund (24-62 m a.s.1.) suggest that most of this uplift had happened by $2.5 \mathrm{Ma}$. So, mantle dynamics can in principle explain the current elevation of the LEF, whereas this is not the case for the KKF farther north, with its distal location to the Icelandic plume thermal anomaly and negative dynamic topography (Steinberger et al., 2015).

Estimates of eustatic sea level during deposition of the late Pliocene-early Pleistocene marine deposits are uncertain. Reported global values for the mid-Pliocene thermal optimum (ca. 3.3-3.0 Ma) range from +10 to $+40 \mathrm{~m}$, but these reconstructions are affected by local non-eustatic sea-level changes such as residual isostatic adjustments associated with recent glaciation (Raymo et al., 2011). Particularly for regions proximal to the GrIS, such effects could diminish or even reverse the reported midPliocene sea-level values (Raymo et al., 2011). Consequently, we do not consider eustatic sealevel changes explicitly for the interpretation of the elevated marine deposits.

\section{RESULTS}

By considering geophysical relief as a proxy for erosion, we get by far the most erosion in fjords and large valleys and less erosion in the adjacent areas, with estimated fjord erosion reflecting local variations in relief (Fig. 1). The dramatic relief in the inner parts of the Scoresby Sund fjord system results in erosion estimates of $>3500 \mathrm{~m}$ (Fig. 1, profile B-B'), whereas the lower relief in Independence Fjord toward the north results in erosion estimates of $<1500 \mathrm{~m}$ (Fig. 1, profile A-A'). Overall, the estimated erosion varies between 0 and $3678 \mathrm{~m}$ for onshore regions and fjords, with an average of $\sim 350 \mathrm{~m}$, and between 0 and $613 \mathrm{~m}$ for the shelf, with an average of $167 \mathrm{~m}$.

The erosion estimates derived from geophysical relief indicate up to $\sim 940 \mathrm{~m}$ of flexural isostatic uplift, with the largest values around Scoresby Sund (Fig. 2). A net surface uplift is 

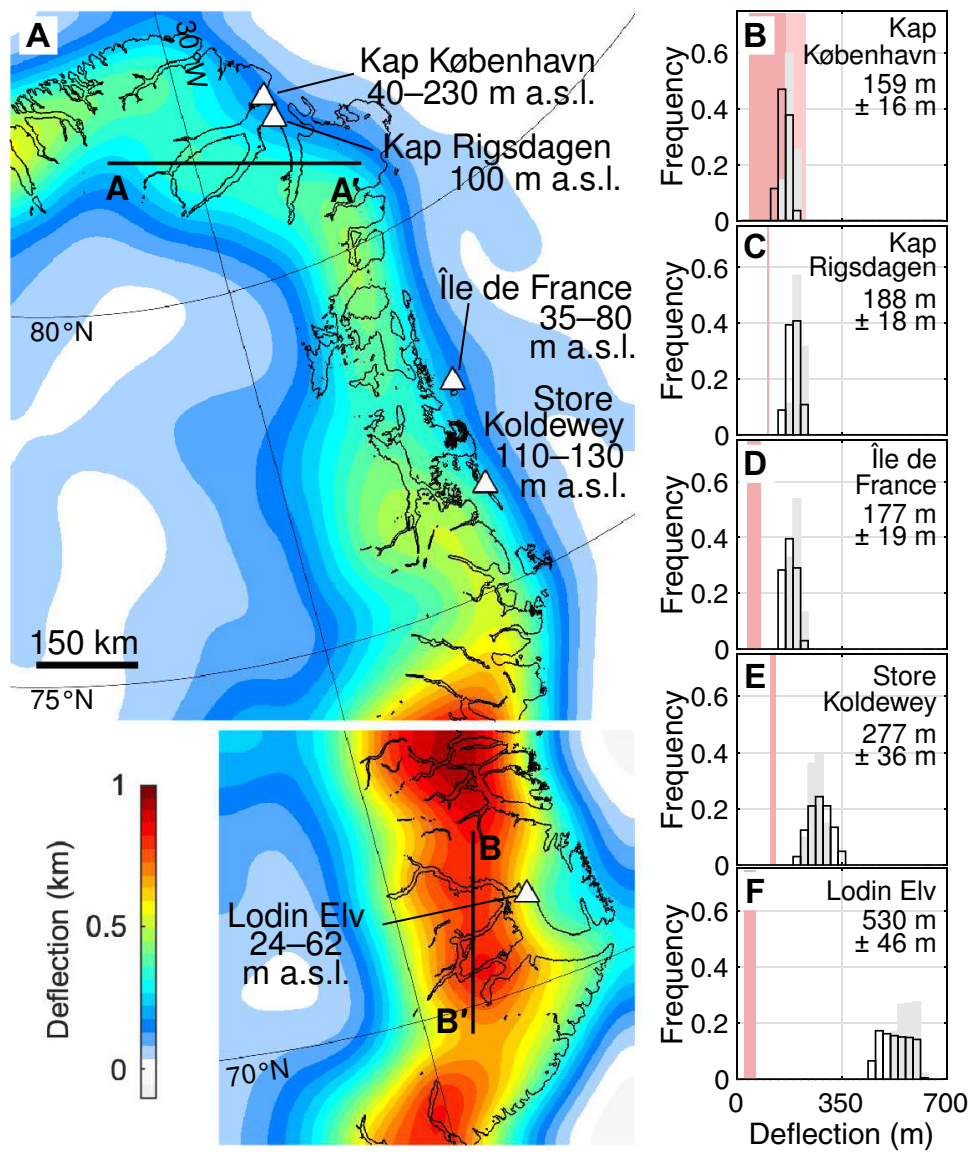

Figure 2. Erosion-driven flexural isostatic uplift. A: Deflection of lithosphere owing to erosional unloading in North and Northeast Greenland for an effective elastic thickness (EET) of $20 \mathrm{~km}$ (a.s.I.-above sea level). For profiles A-A' and B-B', see Figure 1. B-F: Present elevation of Kap København Formation and related sequences (red bands), compared to the deflection distribution in a $30 \times 30 \mathrm{~km}$ window around the localities (histograms, black outline). Mean and standard deviation are indicated for deflection distributions. Gray histograms represent similar deflection distributions, but for an EET of $40 \mathrm{~km}$ (see Figs. DR2-DR3 [see footnote 1] for full details). We note that the choice of EET does not affect our results significantly. Note that for the Kap København Formation, light red color indicates observations, which might reflect post-depositional glaciotectonic dislocation (Funder et al., 1984), although most sections are undisturbed sediment successions (Bennike, 1990).
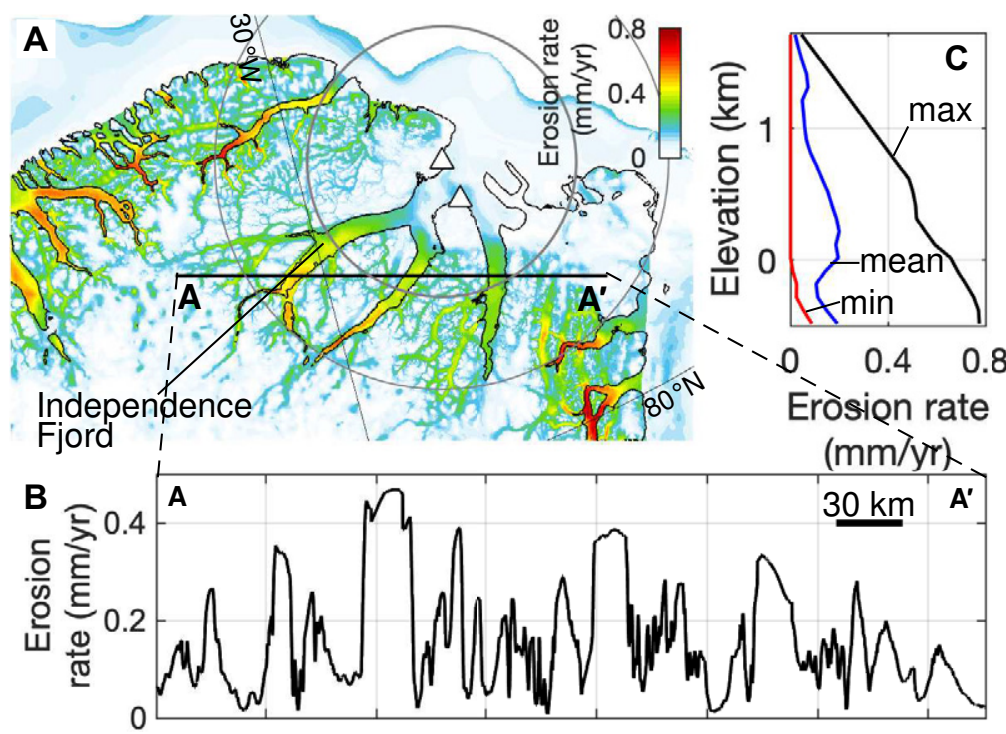

achieved when the estimated erosion is smaller than the isostatic uplift, and accounts for up to $\sim 935 \mathrm{~m}$ of surface uplift in the high regions surrounding Scoresby Sund.

In order to compare our estimates of erosioninduced uplift with the present elevation of the marine deposits, we evaluate the isostatic deflection in $30 \times 30 \mathrm{~km}$ windows around each locality (Figs. 2B-2F, histograms). We find good agreement between the erosion-induced uplift and the present elevation of the KKF (Fig. 2B), whereas there is a mismatch for the other localities. The mismatch increases toward the south, reaching $>450 \mathrm{~m}$ for the LEF (Figs. 2C-2F).

\section{DISCUSSION}

\section{Glacial Erosion and Isostatic Uplift}

Our estimates of erosion-induced isostatic uplift are some $15 \%$ lower than previous estimates from the region (Medvedev et al., 2008, 2013, 2018). Compared to these previous findings, our approach leads to more conservative estimates of erosion, assuming only a modest component of erosion $(<500 \mathrm{~m})$ in regions outside fjords and large valleys, which is what we expect for glacial erosion (Sugden, 1974; Egholm et al., 2017; Strunk et al., 2017; Andersen et al., 2018).

We find that both complete fjord formation and additional modest erosion in adjacent areas are needed in order to explain the amount of uplift observed for the KKF since 2.5 Ma (Fig. 2B), even when considering a potential sea-level change of some $10-40 \mathrm{~m}$. This suggests that most glacial erosion in North Greenland occurred within the last 2.5 m.y. Assuming that our estimated erosion has taken place at a constant rate since deposition of the KKF, fjord erosion rates amount to $>0.5 \mathrm{~mm} / \mathrm{yr}$ in many places, with rates locally approaching $0.8 \mathrm{~mm} / \mathrm{yr}$ (Fig. 3). Estimated erosion rates are

Figure 3. Quaternary erosion rates in North Greenland. A: Erosion rates, assuming constant rates over 2.5 m.y., based on erosion estimates in Figure 1B. Gray circles illustrate the contributing area for erosion-induced isostatic uplift for the Kap Kobenhavn Formation, with the radius defined as the half-width of the analytical line-load depression (Turcotte and Schubert, 2002) for an effective elastic thickness of $20 \mathrm{~km}$ (inner circle) and 40 km (outer circle), respectively. B: Erosion rates across profile $A-A^{\prime}$, also shown in Figure 1. C: Minimum, mean, and maximum erosion rates with elevation for the region shown in $\mathrm{A}$. 
significantly lower at high elevations between fjords, where the geophysical relief method predicts limited erosion (Figs. 3B and 3C). If we assume that fjord incision is limited to glacial periods-suggested to constitute a maximum of $45 \%$ of the last 2.5 m.y. in western Greenland (Strunk et al., 2017)—erosion rates would have been $>1 \mathrm{~mm} / \mathrm{yr}$. A younger age of ca. 2.0 Ma for part of the KKF (Bennike et al., 2010) would raise the rate further to $\sim 1.4 \mathrm{~mm} / \mathrm{yr}$. We stress that these rates are minimum estimates, as the KKF and related sequences could have extended to higher elevations previously, as indicated by their upper erosive surfaces (e.g., FeylingHanssen et al., 1983; Funder et al., 1984).

The large mismatch we find between our estimates of erosion-driven uplift and the present elevation of the LEF in Scoresby Sund suggests that at least some of the predicted erosion must have taken place prior to deposition of the LEF at ca. 2.5 Ma. Either the majority of the erosion and fjord formation had already occurred in the broader region by $2.5 \mathrm{Ma}$, or extensive fjord erosion had propagated a significant distance inland from the Lodin Elv locality at the time of deposition. In order to explore the implications of this latter view of fjord propagation, we split our isostatic uplift estimates into four components, based on the erosion from four separate domains, with varying proximity to the LEF (Fig. 4, regions 1-4). From this, it becomes evident that erosion of the outermost regions 3-4 would have contributed considerably to uplift of the LEF, and a significant portion of this erosion must have taken place prior to $2.5 \mathrm{Ma}$. In contrast, erosion in regions 1-2 would not have contributed to uplift, but may have induced minor subsidence at the LEF locality, and therefore we cannot resolve the timing and amplitude of this erosion. However, based on numerical modeling studies (e.g., Pedersen et al., 2014; Egholm et al., 2017), we find it plausible that glacial erosion and fjord formation have propagated inland since glacial erosion commenced and as the fjord system has evolved.

As noted previously, mantle dynamics can in principle explain the current elevation of the LEF (Steinberger et al., 2015). This would point to a larger component of pre-Pleistocene glacial erosion in the Scoresby Sund region, with more erosion from regions 3-4 taking place prior to $2.5 \mathrm{Ma}$ (Fig. 4). Finally, we note that a higher sea level during deposition of the late Pliocene-early Pleistocene marine deposits would imply that less erosion has occurred since $2.5 \mathrm{Ma}$, whereas a lower sea level would imply the opposite. However, the current lack of an accurate late Pliocene-early Pleistocene sea-level reconstruction prevents us from assessing these effects further (Raymo et al., 2011).

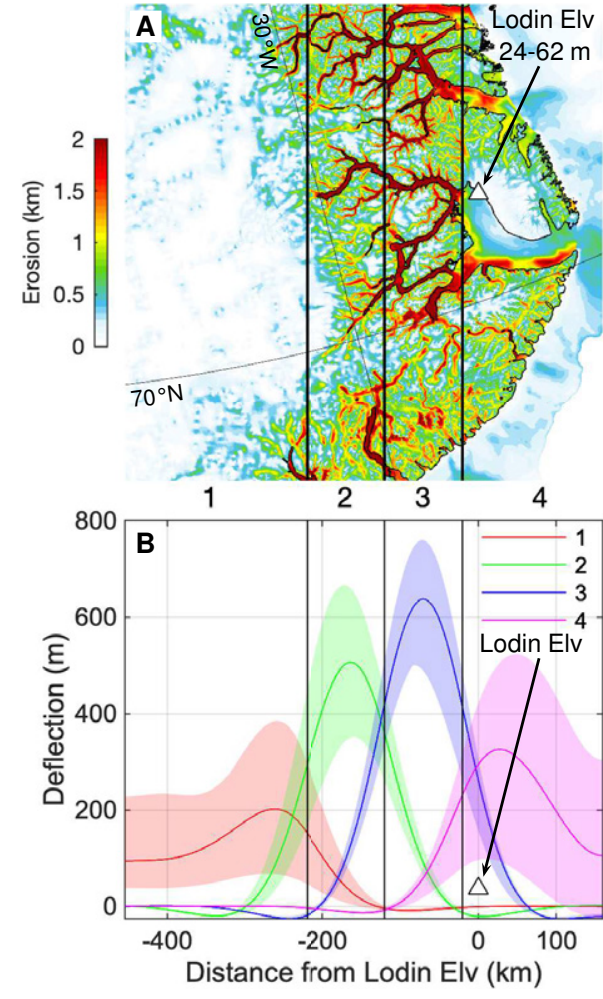

Figure 4. Erosion-driven flexural isostatic uplift from different domains. A: Estimated erosion using the geophysical relief method for the Scoresby Sund region (Northeast Greenland, $70^{\circ} \mathrm{N}$ ). Black lines separate four different domains with varying proximity to the Lodin Elv locality. B: Minimum, mean, and maximum deflections for each of the four domains in $A$, plotted with respect to location of the Lodin Elv Formation.

\section{Inception and Evolution of the Greenland Ice Sheet}

Our study implies that extensive glacial erosion and fjord formation in North and Northeast Greenland did not commence synchronously. In North Greenland, extensive glacial erosion was limited to the Pleistocene, with the relief of the Independence fjord system developing after deposition of the KKF at ca. 2.5 Ma. In contrast, extensive glacial erosion commenced earlier farther south in Scoresby Sund, Northeast Greenland, with only limited glacial erosion taking place after 2.5 Ma near the LEF location. This implies that the main source of ice-rafted debris (IRD) material dating back before the Pleistocene was Northeast Greenland, or regions outside of our study area. This view is consistent with recent work using Feoxide fingerprinting pointing to Northeast and Southeast Greenland as the main sources for Eocene-Oligocene IRD (Tripati and Darby, 2018), and other studies suggesting extensive glacial erosion in particular in Northeast and Southeast Greenland prior to the Pleistocene (e.g., Larsen et al., 1994; Eldrett et al., 2007; Bernard, et al., 2016; Bierman et al., 2016). The lack of extensive, relief-forming glacial ero- sion in North Greenland near the KKF prior to $2.5 \mathrm{Ma}$ implies that widespread and fjordforming glaciations did not commence in this region before 2.5 Ma. Farther south in Scoresby Sund, our results imply that widespread and prolonged glaciations commenced earlier, with a main phase of glacial erosion proximal to the LEF taking place prior to $2.5 \mathrm{Ma}$ and probably as early as the late Miocene (ca. $7 \mathrm{Ma}$ ), or even the Eocene-Oligocene transition, as indicated by the IRD records offshore Northeast Greenland (e.g., Larsen et al., 1994; St. John and Krissek, 2002; Tripati and Darby, 2018).

\section{CONCLUSION}

We have evaluated the timing of extensive glacial erosion and fjord formation in North and Northeast Greenland using elevated marine sediments of late Pliocene-early Pleistocene age. By constraining the timing of fjord formation, we constrain the timing of widespread and prolonged glaciation in these regions. We find that in North Greenland, the full relief of the Independence Fjord system must have developed since ca. 2.5 Ma in order to explain the current elevation of the marine KKF by the flexural isostatic response to erosional unloading. This implies glacial erosion rates in the fjords $>0.5 \mathrm{~mm} / \mathrm{yr}$ over a $2.5 \mathrm{~m}$.y. time period, or rates $>1 \mathrm{~mm} / \mathrm{yr}$ if erosion is limited to glacial periods which constitute a maximum of $45 \%$ of the last 2.5 Ma. Consistent with patterns in present topography, our study suggests that extensive and prolonged glaciation did not extend to North Greenland before $2.5 \mathrm{Ma}$, whereas glaciation and glacial erosion commenced before $2.5 \mathrm{Ma}$ farther south around Scoresby Sund.

\section{ACKNOWLEDGMENTS}

This project has received funding from the European Union's Horizon 2020 research and innovation program under the Marie Skłodowska-Curie grant agreement 745669. Pedersen and Larsen thank the Villum Foundation's Young Investigator Programme for their support (grants 15467 and 023440 , respectively). We thank Sergei Medvedev and two anonymous reviewers for detailed and constructive comments.

\section{REFERENCES CITED}

Andersen, J.L., et al., 2018, Widespread erosion on high plateaus during recent glaciations in Scandinavia: Nature Communications, v. 9, 830, https:// doi.org/10.1038/s41467-018-03280-2.

Bennike, O., 1990, The Kap København Formation: Stratigraphy and palaeobotany of a Plio-Pleistocene sequence in Peary Land, North Greenland: Meddelelser om Grønland, v. 23, p. 3-85.

Bennike, O., and Böcher, J., 1990, Forest-tundra neighbouring the North Pole: Plant and insect remains from the Plio-Pleistocene Kap København Formation, North Greenland: Arctic, v. 43, p. 331-338, https://doi.org/10.14430/arctic1629.

Bennike, O., Abrahamsen, N., Bak, M., Israelson, C., Konradi, P., Matthiessen, J., and Witkowski, A., 2002, A multi-proxy study of Pliocene sediments from Île de France, North-East Greenland: Palaeogeography, Palaeoclimatology, 
Palaeoecology, v. 186, p. 1-23, https://doi.org /10.1016/S0031-0182(02)00439-X.

Bennike, O., Knudsen, K.L., Abrahamsen, N., Böcher, J., Cremer, H., and Wagner, B., 2010, Early Pleistocene sediments on Store Koldewey, northeast Greenland: Boreas v. 39, p. 603-619, https:// doi.org/10.1111/j.1502-3885.2010.00147.x.

Berger, D., and Jokat, W., 2008, A seismic study along the East Greenland margin from $72^{\circ} \mathrm{N}$ to $77^{\circ} \mathrm{N}$ : Geophysical Journal International, v. 174, p. 733-748, https://doi.org/10.1111/j.1365-246X 2008.03794.x.

Bernard, T., Steer, P., Gallagher, K., Szulc, A., Whitham, A., and Johnson, C., 2016, Evidence for Eocene-Oligocene glaciation in the landscape of the East Greenland margin: Geology, v. 44, p. 895-898, https://doi.org/10.1130/G38248.1.

Bierman, P.R., Corbett, L.B., Graly, J.A., Neumann, T.A., Lini, A., Crosby, B.T., and Rood, D.H., 2014, Preservation of a preglacial landscape under the center of the Greenland Ice Sheet: Science, v. 344, p. 402-405, https://doi.org/10.1126 /science. 1249047

Bierman, P.R., Shakun, J.D., Corbett, L.B., Zimmerman, S.R., and Rood, D.H., 2016, A persistent and dynamic East Greenland Ice Sheet over the past 7.5 million years: Nature, v. 540, p. 256-260, https://doi.org/10.1038/nature20147.

Butt, F.A., Elverhøi, A., Forsberg, C.F., and Solheim, A., 2001, Evolution of the Scoresby Sund Fan, central East Greenland-Evidence from ODP Site 987: Norsk Geologisk Tidsskrift, v. 81, p. 3-15.

Champagnac, J.D., Molnar, P., Anderson, R.S., Sue, C., and Delacou, B., 2007, Quaternary erosioninduced isostatic rebound in the western Alps: Geology, v. 35, p. 195-198, https://doi.org/10 1130/G23053A.1.

Egholm, D.L., Jansen, J.D., Brædstrup, C.F., Pedersen, V.K., Andersen, J.L., Uglevig, S.V., Larsen, N.K., and Knudsen, M.F., 2017, Formation of plateau landscapes on glaciated continental margins: Nature Geoscience, v. 10, p. 592-597, https://doi.org /10.1038/ngeo 2980

Eldrett, J.S., Harding, I.C., Wilson, P.A., Butler, E., Roberts, A.P., 2007. Continental ice in Greenland during the Eocene and Oligocene: Nature, v. 446, p. 176-179. https://doi.org/10.1038/nature05591.

Feyling-Hanssen, R.W., Funder, S., and Petersen, K.S., 1983, The Lodin Elv Formation: A Plio-Pleistocene occurrence in Greenland: Bulletin of the Geological Society of Denmark, v. 31, p. 81-106.

Funder, S., and Hjort, C., 1980, A reconnaissance of the Quaternary geology of eastern North Greenland: Grønlands Geologiske Undersøgelse, v. 99, p. 99-105.

Funder, S., Bennike, O., Mogensen, G.S., NoeNygaard, B., Pedersen, S.A.S., and Petersen, K.S., 1984, The Kap København Formation, a late Cainozoic sedimentary sequence in North Greenland: Grønlands Geologiske Undersøgelse, v. 120 , p. $9-18$.

Funder, S., Abrahamsen, N., Bennike, O., and FeylingHanssen, R.W., 1985, Forested Arctic: Evidence from North Greenland: Geology, v. 13, p. 542 546, https://doi.org/10.1130/0091-7613(1985)13 $<542$ :FAEFNG $>2.0 . \mathrm{CO} ; 2$

Funder, S., Bennike, O., Böcher, J., Israelson, C., Petersen, K.S., and Simonarson, L.A., 2001, Late Pliocene Greenland-The Kap København Formation in North Greenland: Bulletin of the Geological Society of Denmark, v. 48, p. 117-134.
Helland, P.E., and Holmes, M.A., 1997, Surface textural analysis of quartz sand grains from ODP Site 918 off the southeast coast of Greenland suggests glaciation of southern Greenland at $11 \mathrm{Ma}$ : Palaeogeography, Palaeoclimatology, Palaeoecology, v. 135, p. 109-121, https://doi.org/10.1016 /S0031-0182(97)00025-4.

Landvik, J.Y., 1994, The last glaciation of Germania Land and adjacent areas, northeast Greenland: Journal of Quaternary Science, v. 9, p. 81-92, https://doi.org/10.1002/jqs.3390090108.

Larsen, H.C., Saunders, A.D., Clift, P.D., Beget, J., Wei, W., Spezzaferri, S., and ODP Leg 152 Scientific Party, 1994, Seven million years of glaciation in Greenland: Science, v. 264, p. 952-955, https:// doi.org/10.1126/science.264.5161.952.

Makhoul, J., 1980, A fast cosine transform in one and two dimensions: IEEE Transactions on Acoustics, Speech, and Signal Processing, v. 28, p. 27-34, https://doi.org/10.1109/TASSP.1980.1163351.

Medvedev, S., Hartz, E.H., and Podladchikov, Y.Y., 2008, Vertical motions of the fjord regions of central East Greenland: Impacts of glacial erosion, deposition, and isostasy: Geology, v. 36 , p. 539-542, https://doi.org/10.1130/G24638A.1.

Medvedev, S., Souche, A., and Hartz, E.H., 2013, Influence of ice sheet and glacial erosion on passive margins of Greenland: Geomorphology, v. 193 p. 36-46, https://doi.org/10.1016/j.geomorph .2013.03.029.

Medvedev, S., Hartz, E.H., and Faleide, J.I., 2018, Erosion-driven vertical motions of the circum Arctic: Comparative analysis of modern topography: Journal of Geodynamics, v. 119, p. 62-81 https://doi.org/10.1016/j.jog.2018.04.003.

Morlighem, M., et al., 2017, BedMachine v3: Complete bed topography and ocean bathymetry mapping of Greenland from multi-beam echo sounding combined with mass conservation: Geophysical Research Letters, v. 44, p. 11,05111,061, https://doi.org/10.1002/2017GL074954.

Pedersen, V.K., Huismans, R.S., Herman, F., and Egholm, D.L., 2014, Controls of initial topography on temporal and spatial patterns of glacial erosion: Geomorphology, v. 223, p. 96-116 https://doi.org/10.1016/j.geomorph.2014.06.028.

Penney, D.N., 1993, Late Pliocene to early Pleistocene ostracod stratigraphy and palaeoclimate of the Lodin Elv and Kap København formations, East Greenland: Palaeogeography, Palaeoclimatology, Palaeoecology, v. 101, p. 49-66, https://doi.org /10.1016/0031-0182(93)90151-8.

Pérez, L.F., Nielsen, T., Knutz, P.C., Kuijpers, A., and Damm, V., 2018, Large-scale evolution of the central-east Greenland margin: New insights to the North Atlantic glaciation history: Global and Planetary Change, v. 163, p. 141-157, https://doi .org/10.1016/j.gloplacha.2017.12.010.

Pérez-Gussinyé, M., Lowry, A.R., Watts, A.B., and Velicogna, I., 2004, On the recovery of effective elastic thickness using spectral methods: Examples from synthetic data and from the Fennoscandian Shield: Journal of Geophysical Research, v. 109, B10409, https://doi.org/10.1029 /2003JB002788.

Raymo, M.E., Mitrovica, J.X., O’Leary, M.J., DeConto, R.M., and Hearty, P.J., 2011, Departures from eustasy in Pliocene sea-level records: Nature Geoscience, v. 4, p. 328-332, https://doi.org /10.1038/ngeo1118.

Schaefer, J.M., Finkel, R.C., Balco, G., Alley, R.B. Caffee, M.W., Briner, J.P., Young, N.E., Gow,
A.J., and Schwartz, R., 2016, Greenland was nearly ice-free for extended periods during the Pleistocene: Nature, v. 540, p. 252-255, https:// doi.org/10.1038/nature20146.

Small, E.E., and Anderson, R.S., 1998, Pleistocene relief production in Laramide mountain ranges, western United States: Geology, v. 26, p. 123-126, https://doi.org/10.1130/0091-7613 (1998)026<0123:PRPILM>2.3.CO;2.

Steer, P., Huismans, R.S., Valla, P.G., Gac, S., and Herman, F., 2012, Bimodal Plio-Quaternary glacial erosion and low-relief surfaces in Scandinavia: Nature Geoscience, v. 5, p. 635-639, https://doi .org/10.1038/ngeo1549.

Steinberger, B., Spakman, W., Japsen, P., and Torvisk, T.H., 2015, The key role of global solid-Earth processes in preconditioning Greenland's glaciation since the Pliocene: Terra Nova, v. 27, p. 1-8, https://doi.org/10.1111/ter.12133.

St. John, K.E.K., and Krissek, L.A., 2002, The late Miocene to Pleistocene ice-rafting history of southeast Greenland: Boreas, v. 31, p. 28-35, https://doi.org/10.1111/j.1502-3885.2002 .tb01053.x.

Strunk, A., Knudsen, M.F., Egholm, D.L., Jansen, J.D., Levy, L.B., Jacobsen, B.H., and Larsen, N.K., 2017, One million years of glaciation and denudation in west Greenland: Nature Communications, v. 8, 14199, https://doi.org/10.1038 /ncomms 14199 .

Sugden, D.E., 1974, Landscapes of glacial erosion in Greenland and their relationship to ice, topographic, and bedrock conditions, in Brown, E.H., and Waters, R.S., eds., Progress in Geomorphology: Papers in Honour of David L. Linton: Institute of British Geographers Special Publication 7 , p. 177-195.

Thiede, J., Winkler, A., Wolf-Welling, T., Eldholm, O., Myhre, A.M., Baumann, K.-H., Henrich, R., and Stein, R., 1998, Late Cenozoic history of the polar North Atlantic: Results from ocean drilling: Quaternary Science Reviews, v. 17, p. 185-208, https://doi.org/10.1016/S0277-3791 (97)00076-0.

Tripati, A.K., et al., 2008, Evidence for Northern Hemisphere glaciation back to $44 \mathrm{Ma}$ from icerafted debris in the Greenland Sea: Earth and Planetary Science Letters, v. 265, p. 112-122, https://doi.org/10.1016/j.eps1.2007.09.045.

Tripati, A., and Darby, D., 2018, Evidence for ephemeral middle Eocene to early Oligocene Greenland glacial ice and pan-Arctic sea ice: Nature Communications, v. 9, 1038, https://doi.org/10.1038 Is41467-018-03180-5.

Turcotte, D.L., and Schubert, G., 2002, Geodynamics (second edition): Cambridge, UK, Cambridge University Press, 456 p., https://doi.org/10.1017 /CBO9780511807442.

Williams, C.N., Cornford, S.L., Jordan, T.M., Dowdeswell, J.A., Siegert, M.J., Clark, C.D., Swift, D.A., Sole, A., Fenty I., and Bamber, J.L., 2017, Generating synthetic fjord bathymetry for coastal Greenland: The Cryosphere, v. 11, p. 363380, https://doi.org/10.5194/tc-11-363-2017.

Winkler, A., Wolf-Welling, T., Stattegger, K., and Thiede, J., 2002, Clay mineral sedimentation in high northern latitude deep-sea basins since the Middle Miocene (ODP Leg 151, NAAG): International Journal of Earth Sciences, v. 91, p. 133148, https://doi.org/10.1007/s005310100199.

Printed in USA 